\title{
Progamotaenia Capricorniensis Sp. Nov. (Cestoda: Anoplocephalidae) FROM WALLABIES (MARSUPIALIA: MACROPODIDAE) FROM QUEENSLAND, AUSTRALIA
}

\author{
BEVERIDGE I.* \& TURNI C.**
}

\section{Summary:}

Progamotaenia capricorniensis sp. nov. (Cestoda:

Anoplocephalidae) is described from the wallabies Macropus dorsalis (Gray, 1837) and Petrogale assimilis Ramsay, 1877 from Queensland, Australia. The new species is characterised by a fimbriated velum composed of 26-32 digitiform to triangular projections on each side of the proglottis, paired uteri and 140-

190 testes distributed in a single band across the medulla. Minor variation occurs in the distribution of the testes. The above characters distinguish the new species from its most closely related congeners P. lagorchestis (Lewis, 1914), P. proterogyna (Fuhrmann, 1932), P. spearei Beveridge, 1980 and $P$. villosa (Lewis, 1914). P. capricorniensis appears to exhibit a highly disjunct distribution within its usual host, $M$. dorsalis.

KEY WORDS : Progamotaenia, Cestoda, Anoplocephalidae, new species, marsupials, wallabies, Australia.

\section{INTRODUCTION}

1 the anoplocephalid genus Progamotaenia Nybelin, 1917 consists of a number of species of cestodes which parasitise the small intestine and bile ducts of kangaroos, wallabies, rat-kangaroos and wombats (Beveridge, 1976, 1978, 1980, 1985; Beveridge \& Thompson, 1979; Turni \& Smales, 1999). Currently, 20 species are recognised within the genus (Table I), although additional undescribed species have been reported (Spratt et al., 1991). In addition, allozyme studies (Baverstock et al., 1985) have suggested that at least one currently recognised species, $P$. festiva (Rudolphi, 1817), consists of at least ten sibling species raising the possibility that other species complexes exist within the genus. As part of a revision of the genus, the unnamed species from the blackstripe wallaby, Macropus dorsalis (Gray, 1837), reported by

\footnotetext{
* Department of Veterinary Science, University of Melbourne, Veterinary Clinical Centre, Werribee, Victoria, 3030, Australia.

** Department of Microbiology and Parasitology, University of Queensland, St Lucia, Queensland, 4072, Australia.

Correspondence: Ian Beveridge.

Tel.: 61397312285 - Fax 61397312263.

E-mail: i.beveridge@vet.unimelb.edu.au
}

Résumé : PROGAMOTAENIA CAPRICORNIENSIS SP. NOV. (CESTODA: ANOPLOCEPHALIDAE) PARASITE DE WALLABIES (MARSUPIALIA: Macropodidae) provenant du Queensland, Australie

Description de Progamotaenia capricorniensis sp. nov. /Cestoda: Anoplocephalidae), parasite de l'intestin grêle des wallabies Macropus dorsalis (Gray, 1837) et Petrogale assimilis Ramsay, 1877. La nouvelle espèce se distingue par le nombre de projections (26-32) du velum sur chaque côté du proglottis, la possession de deux utéri dans chaque proglottis et la possession de 140-190 testicules distribués dans une bande antérieure de l'utérus. Ces caractères distinguent la nouvelle espèce des espèce voisines: P. lagorchestis (Lewis, 1914), P. proterogyna (Fuhrmann 1933), P. spearei Beveridge, 1980 et P. villosa (Lewis, 1914). La distribution géographique de la nouvelle espèce semble être extrêmement dispersée à l'intérieur de l'aire de répartition de I'hôte, M. dorsalis.

MOTS CLÉS : Progamotaenia, Cestoda, Anoplocephalidae, nouvelle espèce, marsupiaux, wallabies, Australie.

Spratt et al. (1991) and Beveridge et al. (1998), is described in this paper and its relationships with congeners are examined.

\section{MATERIALS AND METHODS}

S pecimens collected by the authors were relaxed in water and fixed in either $10 \%$ formalin or AFA (Pritchard \& Kruse, 1982). Cestodes were stained in carmine or celestine blue, dehydrated in ethanol, cleared in clove oil or methyl salicylate and mounted in Canada balsam. After clearing, the tegument and longitudinal muscles of most specimens were removed using fine forceps. Some proglottides were sectioned by hand using a scalpel blade to provide cross sections of the proglottis. Additional proglottides were embedded in paraffin, sectioned at a thickness of $5 \mu \mathrm{m}$ and the sections were stained with haematoxylin and eosin. Eggs were expelled from gravid proglottides and examined in water before clearing in lactophenol. Drawings were made with the aid of a drawing tube attached to an Olympus BH-2 microscope. Measurements were made with a ruler or with an ocular micrometer. All measurements are presented in millimetres as the mean followed, in parentheses, by the range and number measurements. 


\begin{tabular}{|c|c|c|c|c|c|}
\hline Species name & Host genera & $\begin{array}{c}\text { Velum: } \\
\text { straight (s) } \\
\text { or laciniate (no.) }\end{array}$ & $\begin{array}{l}\text { Testis } \\
\text { groups }\end{array}$ & $\begin{array}{l}\text { Testis } \\
\text { no. }\end{array}$ & $\begin{array}{c}\text { No. } \\
\text { of uteri }\end{array}$ \\
\hline abietiformis Turni \& Smales, 1999 & Onychogalea & $12-16$ & 2 & $11-13$ & 2 \\
\hline aepyprymni Beveridge, 1976 & Aepyprymnus & S & 1 & $35-46$ & 2 \\
\hline bancrofti (Johnston, 1912) & Onychogalea & S & 2 & c. 200 & 2 \\
\hline capricorniensis sp. $\mathrm{n}$. & Macropus & $26-32$ & $1(2)^{*}$ & $142-191$ & 2 \\
\hline diaphana (Zschokke, 1907) & Lasiorbinus & S & $2(1)$ & $39-64$ & 2 \\
\hline dorcopsis Beveridge, 1985 & Dorcopsis & $13-17$ & 2 & $34-50$ & 2 \\
\hline effigia Beveridge, 1976 & Macropus & S & $1(2)$ & $67-96$ & 1 \\
\hline ewersi (Schmidt, 1975) & Macropus, Wallabia & S & 1 & $102-140$ & 1 \\
\hline festiva (Rudolphi, 1817) & $\begin{array}{l}\text { Macropus, Wallabia, } \\
\text { Onychogalea, Setonix, } \\
\text { Vombatus, Lagorchestes }\end{array}$ & $\mathrm{S}$ & $1(2)$ & $22-65$ & 2 \\
\hline gynandrolinearis Beveridge \& Thompson, 1979 & Lagorchestes & S & 1 & c. 50 & 2 \\
\hline jobnsoni Beveridge, 1980 & Lagorchestes & S & 2 & $100-190$ & 2 \\
\hline lagorchestis (Lewis, 1914) & Lagorchestes & $20-35$ & 2 & $70-90$ & 2 \\
\hline macropodis Beveridge, 1976 & Macropus, Wallabia & S & 1,2 & $80-149$ & 2 \\
\hline proterogyna (Fuhrmann, 1932) & Macropus & 25 & 1 & $65-80$ & 2 \\
\hline queenslandensis Beveridge, 1985 & Thylogale & $17-20$ & $2(1)$ & $43-50$ & 2 \\
\hline ruficola Beveridge, 1978 & Macropus & S & $2(1)$ & $114-140$ & 2 \\
\hline spearei Beveridge, 1980 & Thylogale & $25-35$ & 2 & $30-40$ & 2 \\
\hline thylogale Beveridge \& Thompson, 1979 & Thylogale & $15-18$ & 2 & $60-100$ & 2 \\
\hline villosa (Lewis, 1914) & Lagorchestes & $24-30$ & 2 & $20-28$ & 2 \\
\hline wallabiae Beveridge, 1985 & Dorcopsis & S & 2 & c. 100 & 2 \\
\hline zschokkei (Janicki, 1906) & $\begin{array}{l}\text { Macropus, Onychogalea, } \\
\text { Lagorchestes, Dendrolagus }\end{array}$ & 12 & 1 & $60-80$ & 1 \\
\hline
\end{tabular}

* Figures in parentheses indicate less common arrangements of testis distribution.

Table I. - Species of Progamotaenia with host genera and principal morphological features.

Specimens have been deposited in the South Australian Museum, Adelaide, South Australia (SAM), the Muséum National d'Histoire Naturelle, Paris (MNHN) and the Natural History Museum, London (BMNH).

\section{RESULTS}

PROGAMOTAENIA CAPRICORNIENSIS SP. NOV. (Figs 1-11)

ynonymy: "Progamotaenia sp. n." of Spratt et al., 1991, p. 49; Beveridge et al. 1998, p. 479 (host: 1 Macropus dorsalis). Progamotaenia cf. queenslandensis Beveridge, 1985 of Beveridge et al. (1989), p. 276 (host: Petrogale assimilis).

Type-host: Macropus dorsalis (Gray, 1837).

Other hosts: Petrogale assimilis Ramsay, 1877.

Site in host: small intestine.

Type-locality: Taunton National Park, Dingo, Queensland, Australia (23 33' S, $149^{\circ} 13^{\prime} \mathrm{E}$ ).

Type material: holotype, coll. C. Turni, 12.viii.1996, SAM 28475; paratypes: same data, three specimens, SAM 28476; serial sections, SAM 28481; one specimen BMNH, 2003.5.6.6; three specimens, coll. C. Turni, 28.ii.1996, 15.vi.1996, 24.x.1996, SAM 28477, 32146; one specimen, coll. C. Turni, 15.vi.1996, MNHN 63 HG CIX, slides 184-186.
Additional material examined: from Macropus dorsalis: two specimens, Rossmoya, Queensland (23 01' S, $150^{\circ}$ 29 ' E), coll. I. Beveridge, 26.x.2000, SAM 28479; two specimens, Milman, Queensland (23 08' S, $150^{\circ} 24^{\prime}$, E), coll. I. Beveridge, 26.ix.1977, SAM 28478, serial sections SAM 28480, spirit material SAM 2280). From Petrogale assimilis Ramsay, 1877: two specimens, "The Pinnacles", $5 \mathrm{~km}$ south of Charters Towers, Queensland (200' S, $145^{\circ} 16^{\prime} \mathrm{E}$ ), coll. R. Close, 15.viii.1982, SAM 22085 (slides), 11937 (spirit material).

\section{DESCRIPTION}

Large cestodes, $242(199-265, \mathrm{n}=8)$ long, maximum width $7.1(6.0-9.0, \mathrm{n}=10)$, composed of c. 560 proglottides. Scolex lacking prominent lobes (Fig. 1), 1.01 $(0.86-1.11, \mathrm{n}=10)$ in diameter; suckers ovoid, 0.40 (0.32-0.45, $\mathrm{n}=10)$ long, $0.34(0.29-0.36, \mathrm{n}=10)$ wide. Neck absent in incompletely relaxed specimens, 1.10 $(0.44-1.73, n=3)$ long in relaxed specimens. Proglottides greatly extended transversely, with broad velum forming 29 (26-32, $\mathrm{n}=10$ ) digitiform lobes on each of dorsal and ventral aspects of proglottis; lobes extending over $1 / 2$ to $3 / 4$ of succeeding proglottis (Figs 7 11). Premature proglottides $0.42(0.37-0.52, \mathrm{n}=10)$ long, $4.79(4.21-5.62, \mathrm{n}=10)$ wide; length of velum $0.32(0.22-0.44, \mathrm{n}=10)$. Mature proglottides $0.48(0.37$ $0.59, \mathrm{n}=10)$ long, $5.80(5.00-6.55, \mathrm{n}=10)$ wide; length 

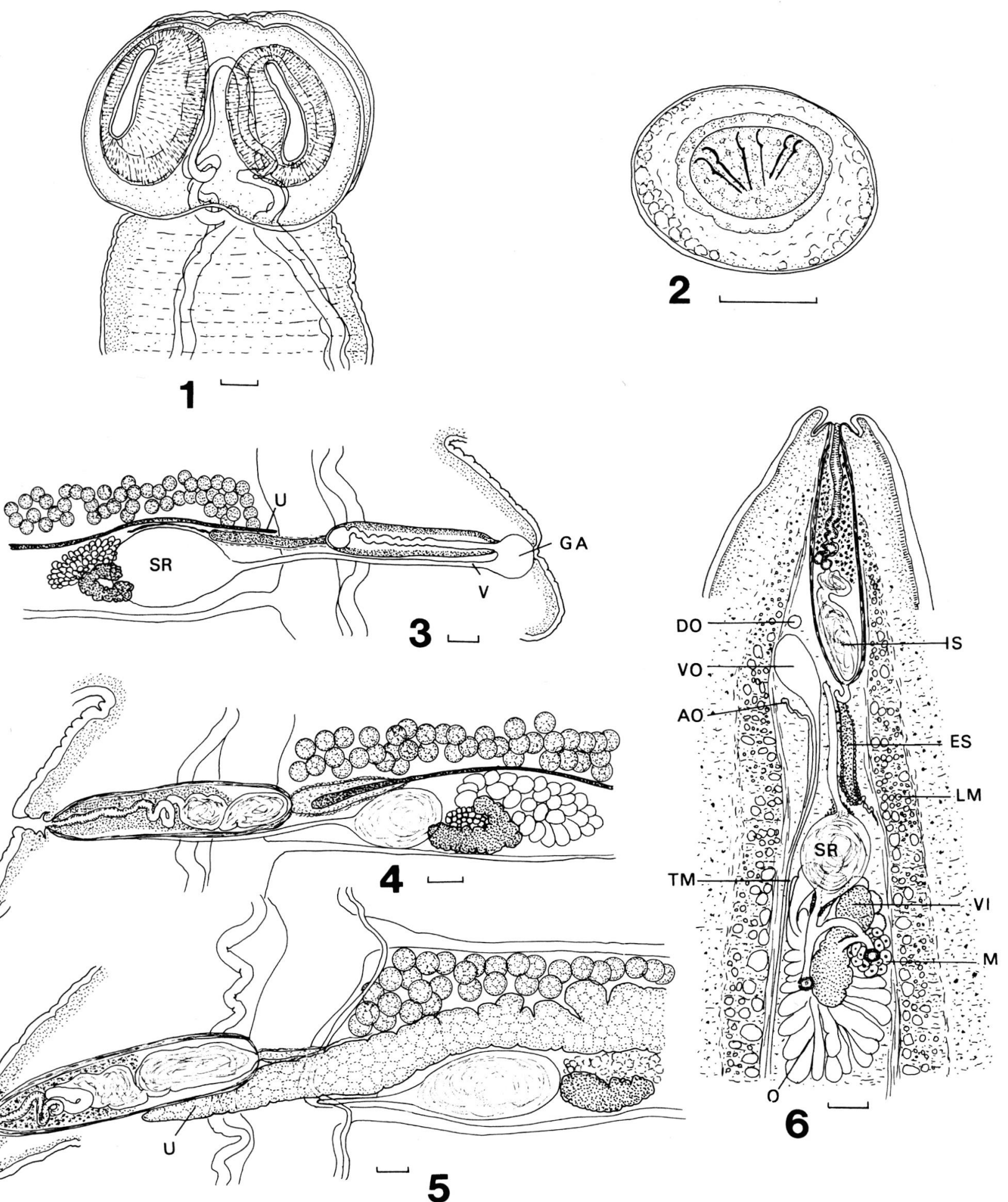

Figs 1-6. - Progamotaenia capricorniensis sp. nov. from Macropus dorsalis (Marsupialia). Fig. 1. Scolex, dorsoventral view. Fig. 2. Egg. Fig. 3. Lateral margin of premature proglottis showing circular genital atrium not opening to exterior and vagina extending from seminal receptacle to genital atrium. Fig. 4. Lateral margin of mature proglottis showing patent genital atrium and cirrus sac with sperm in internal seminal vesicle. Fig. 5. Lateral margin of postmature proglottis showing uterus starting to extend across osmoregulatory canals towards posterolateral margin of proglottis and vagina reduced to blind tube extending laterally from seminal receptacle but scarcely reaching osmoregulatory canals. Fig. 6. Transverse histological section of proglottis showing musculature and genital ducts passing osmoregulatory canals dorsally. Scale-lines: Figs 1, 3-6, $0.1 \mathrm{~mm}$; Fig. 2, $0.01 \mathrm{~mm}$. Abbreviations: AO, accessory osmoregulatory canal; DO, dorsal osmoregulatory canal; ES, external seminal vesicle; GA, genital atrium; IS, internal seminal vesicle; LM, inner longitudinal muscles; M, Mehlis' gland; O, ovary; SR, seminal receptacle; TM, transverse muscle; U, uterus; V, vagina; VI, vitellarium; VO, ventral osmoregulatory canal. 

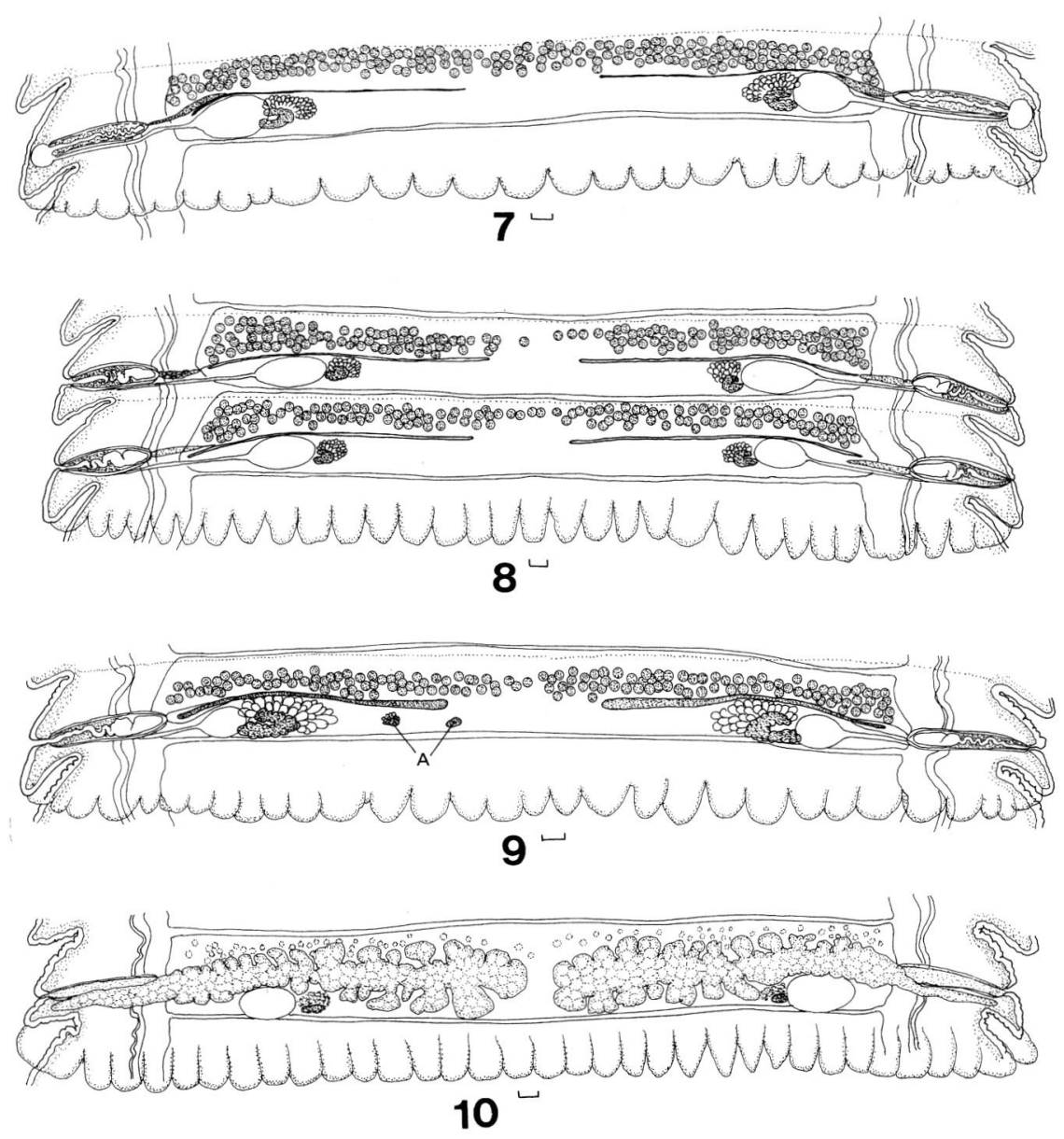

Figs 7-11. - Progamotaenia capricorniensis sp. nov. from Macropus dorsalis, showing sequential development of genitalia. Fig. 7. Premature proglottis prior to patency of genital atria. Fig. 8. Premature proglottides with patent genital atria but with testes distributed either in a single row in middle of proglottis or divided into two groups. Fig. 9. Mature proglottis with extranumerary vestigial vitellaria medial to principal vitellarium. Fig. 10. Postmature proglottis showing uterus extending posterior to cirrus sac but with remnants of testes still visible. Fig. 11. Gravid proglottis. Scale- lines: $0.1 \mathrm{~mm}$. Abbreviations: A. accessory, vestigial vitellaria.

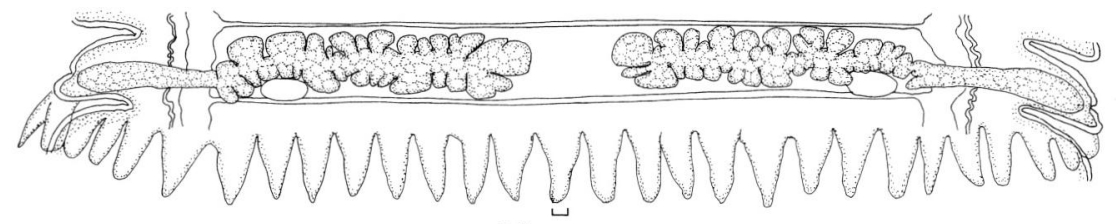

11

of velum $0.41(0.26-0.56, \mathrm{n}=10)$. Postmature proglottides $0.53(0.47-0.59, \mathrm{n}=10)$ long, $6.66(6.16-7.25, \mathrm{n}=$ 10) wide; length of velum $0.44(0.20-0.55, \mathrm{n}=10)$. Gravid proglottides $0.66(0.48-0.94, \mathrm{n}=10)$ long, 5.81 $(4.91-7.18, \mathrm{n}=10)$ wide; length of velum $0.55(0.37$ $0.86, \mathrm{n}=10)$.

Inner longitudinal musculature well developed, composed of large bundles; bundles circular in cross section, each composed on numerous individual fibres; bundles closer to medulla larger, composed of greater number of individual fibres than bundles furthest from medulla (Fig. 6); outer longitudinal muscles consist of individual fibres. Transverse muscles well developed, forming band immediately internal to longitudinal muscles. Dorsoventral muscles arranged as individual fibres; most prominent in cortex, separating rows on longitudinal muscle bundles; few, scattered dorsoventral muscle fibres cross medulla.
Longitudinal osmoregulatory canals paired. In scolex, dorsal and ventral canals of each side fuse at level of anterior part of suckers; single canal joins common canals from each side of strobila near anterior extremity of scolex (Fig. 1). In strobila, dorsal canal external to ventral canal (Fig. 5). Dorsal canal, narrow, sinuous, $0.045(0.039-0.062, \mathrm{n}=10)$ in diameter; ventral canal broader, almost straight, $0.23(0.16-0.37, \mathrm{n}=10)$ in diameter. At posterior margin of each proglottis, ventral but not dorsal canals joined by single transverse canal, $0.04(0.03-0.05, \mathrm{n}=10)$ in diameter. Tiny accessory osmoregulatory canals present, medial and either dorsal or ventral to ventral canal, 0.015 in diameter; accessory canals occasionally have transverse canals joining those from both sides. Genital ducts cross osmoregulatory canals dorsally (Fig. 6).

Genitalia paired. Genital atrium shallow, opening in middle of lateral proglottis margin. Genital atrium in 
premature proglottides circular in dorsoventral views, non-patent (Fig. 3). In mature proglottides, atrium patent, consisting of shallow depression with few folds in margin (Fig. 4). Cirrus sac well developed, with thick muscular wall, extending across osmoregulatory canals, entering medulla, $0.68(0.56-0.76, \mathrm{n}=10)$ long, 0.16 $(0.13-0.18, \mathrm{n}=10)$ wide in mature proglottides (Figs 4 , 5). Distal region of withdrawn cirrus sinuous or straight, armed with small spines; proximal region coiled, unarmed; cirrus surrounded by masses of deeply staining glandular cells. Internal seminal vesicle prominent, usually but not invariably divided into two sections (FIgs 4, 5); distal section $0.20(0.12-0.31, \mathrm{n}=10)$ long, $0.11(0.09-0.13, \mathrm{n}=10)$ wide; proximal section 0.18 (0.13-0.27, $\mathrm{n}=10)$ long, $0.11(0.07-0.14, \mathrm{n}=10)$ wide. External seminal vesicle fusiform, covered with single layer of glandular cells, $0.37(0.27-0.59, \mathrm{n}=10)$ long, $0.07(0.04-0.12, \mathrm{n}=10)$ wide, extending from proximal pole of cirrus sac to midway anterior to seminal receptacle (Fig. 3). Testes spherical, 0.07 (0.05-0.09, $\mathrm{n}=10)$ in diameter, extending in broad band anterior to uteri from median border of ventral osmoregulatory canals (Fig. 7); band 1-4 testes broad anteroposteriorly, 1-3 deep dorsoventrally; testes more densely packed towards lateral extremities of medulla; testes number $170(142-191, \mathrm{n}=10)$; in small number of proglottides, band of testes thins in middle to single row (Fig. 8); in very small number of proglottides, row broken in middle of medulla with testes forming two groups (Fig. 8); all patterns visible within individual cestode; no individual has large number of proglottides with testes divided into two groups.

Vagina narrow tube, $0.02(0.01-0.05, \mathrm{n}=10)$ in diameter, opens to genital atrium posterior to cirrus sac, lacking surrounding investment of glandular cells (Figs 3, $4)$; runs posterior to cirrus sac to ovoid seminal receptacle, $0.38(0.25-0.57, \mathrm{n}=10)$ long, $0.22(0.14-0.29, \mathrm{n}=$ 10) wide. Distal vagina clearly visible in premature proglottides, prior to patency of genital atrium (Fig. 3); following patency of atrium, distal vagina atrophies; in post-mature proglottides vagina consists of short duct extending from seminal receptacle to osmoregulatory canals but not beyond (Fig. 6). Ovary flabelliform, on medial margin of seminal receptacle, $0.56(0.48-0.62$, $\mathrm{n}=10)$ long, $0.27(0.19-0.39, \mathrm{n}=10)$ wide, composed of numerous clavate lobules, on ventral aspect of medulla (Fig. 4). Vitellarium compact, U-shaped, posterior and dorsal to ovary, $0.33(0.27-0.36, \mathrm{n}=10)$ long, 0.15 (0.11-0.19, $\mathrm{n}=10)$ wide. Mehlis' gland spherical, dorsal to and enclosed by recurrent arm of vitellarium, visible in few proglottides only, $0.14(0.10-0.17, \mathrm{n}=5)$ by $0.09(0.06-0.12, \mathrm{n}=5)$. Supranumerary, vestigial vitellaria medial to principal vitellarium in some proglottides (Fig. 9).

Uteri paired, transverse, tubiform, extend from near centre of proglottis, anterior to ovary and seminal receptacle, terminating near medial margin of ventral osmoregulatory canal, anterior to external seminal vesicle (Fig. 8). Uteri subsequently develop both anterior and posterior diverticula while paired digitiform outgrowths cross osmoregulatory canals dorsally and extend to posterolateral aspect of proglottis, posterior to cirrus sac (Figs 10, 11). Eggs ovoid with rough shells, 0.035 (0.031-0.039, $\mathrm{n}=10)$ long, $0.027(0.025-0.027, \mathrm{n}=$ 10) wide; oncosphere $0.018(0.014-0.020, \mathrm{n}=10)$ in diameter; pyriform apparatus absent (Fig. 2).

\section{DISCUSSION}

T the species of Progamotaenia described above is characterised by paired uteri, a fimbriated or laciniate velum with 26-32 digitiform projections and testes usually distributed in a single band anterior to the uteri, numbering 140-190. It is therefore differentiated from all congeners since those species with two uteri and a velum composed of large numbers of posteriorly directed digitiform processes ( $P$. lagorchestis (Lewis, 1914), P. spearei Beveridge, 1980, P. villosa (Lewis, 1914)) have testes distributed in two distinct groups and numbering 20-90 per proglottis (Table I). Of the species with a fimbriated velum, two uteri and testes distributed in a single band, only P. proterogyna (Fuhrmann, 1932) resembles the species described above, but it has only 65-80 testes per proglottis compared with 140-190 in the species described.

Some variation occurs within the genus in the separation of the testes into two lateral groups. Most species are clearly separable into those with two distinct groups and those with a single continuous band of testes. However, some variation does occur within P. diaphana (Zschokke, 1907), P. festiva (Rudolphi, 1817), P. macropodis Beveridge, 1976, P. queenslandensis Beveridge, 1985 and $P$. ruficola Beveridge, 1978 , the significance of which was discussed by Beveridge (1985). In the species described above, the slight separation of testes into two groups occurs in a few proglottides only and in these cases, the majority of proglottides in the same strobila exhibit testes distributed in a single band. Consequently, P. capricorniensis is considered to have the testes distributed in a single band in spite of the fact that in a small number of proglottides, there may be a slight break in testis distribution in the centre of the proglottis. The species described here therefore clearly differs from all previously described species and is considered to be new. The name is given in recognition of the fact that most collections have been made in the Capricornia region of central Queensland.

Several aspects of the morphology of the new species warrant comment. The internal seminal vesicle in 
many, but not all specimens, appears to consist of two dilatations. The proximal dilatation, the true internal seminal vesicle, is invariably present, while in most proglottides the proximal region of the cirrus becomes extremely dilated so as to form an additional component to the internal vesicle. As it is not invariably present, it has not been included in the characters defining the species. It does, however, provide a useful character in separating most specimens of $P$. capricorniensis from congeners.

A pyriform apparatus was not observed in eggs from the specimens examined. It is possible that the cestodes described were not fully gravid, though this is highly unlikely given the number of large specimens of the species available. A pyriform apparatus is also absent in $P$. bancrofti (Johnston, 1912), P. lagorchestis, P. queenslandensis and P. wallabiae Beveridge, 1985 (Beveridge \& Thompson, 1979; Beveridge, 1980, 1985). However, Beveridge (1976) observed that in P. ewersi (Schmidt, 1975), a pyriform appparatus may develop only after the proglottides have been shed. The same may apply to the species noted, as well as to P. capricorniensis. The occurrence of vaginal atrophy is a characteristic of many species Progamotaenia, with the temporal relationships of insemination and atrophy of the vagina being of specific value (Beveridge, 1976). In P. capricorniensis, the precise sequence of relationships could not be determined. In premature proglottides, the full extent of the vagina from the seminal receptacle to the genital atrium was clearly observable. In these proglottides, the genital atrium was subcircular in dorsoventral view (Fig. 3) but did not open to the exterior. In subsequent proglottides, in which the genital atrium opened to the exterior and consisted of folded walls, the vagina could not be traced to the atrium, suggesting that insemination occurs prior to the genital atrium opening to the exterior. This observation needs to be examined in detail using longitudinal serial sections of the anterior regions of cestodes. If confirmed, it represents a novel form of development within the genus. In most species of Progamotaenia, two transverse osmoregulatory canals are present (Beveridge, 1976, $1978,1980,1985)$. In P. capricomiensis, a single transverse canal connects left and right ventral canals in each proglottis. In this respect, $P$. capricorniensis resembles $P$. ewersi (Schmidt, 1975), P. gynandrolinearis Beveridge \& Thompson, 1979, P. johnsoni Beveridge, 1980, P. lagorchestis and P. ruficola.

Beveridge et al. (1998) reported helminths from 39 $M$. dorsalis from central and northern Queensland, with P. capricomiensis (as "Progamotaenia sp. n.") occurring at only a single locality, Milman north of Rockhampton. Subsequent collecting (unpublished observations) has supported this observation, with the cestode being found in $M$. dorsalis only to the north of Rockhampton (Milman, Rossmoya) and to the west
(Dingo). East of Rockhampton, a significant number of specimens of $M$. dorsalis has been examined (Beveridge et al., 1998) without finding P. capricorniensis. Consequently, the distribution of this cestode is thought to be highly disjunct. This hypothesis is supported by the finding of a single infection in the rock wallaby Petrogale assimilis. Beveridge et al. (1989) examined 36 rock wallabies of this species, finding infection of $P$. capricorniensis (reported as " $P$. cf. queenslandensis" in a single specimen only, collected near Charters Towers, Queensland. Additional examination of specimens of $P$. assimilis have failed to reveal examples of this cestode (unpublished observations) supporting the original observations that the species is uncommon in this host. Equally interesting is the fact that a substantial proportion of the sample of $M$. dorsalis examined by Beveridge et al. (1998) was from the Charters Towers region, but no $P$. capricorniensis were found. These data further support the hypothesis that the distribution of the cestode is highly disjunct.

\section{ACKNOWLEDGEMENTS}

T This work was supported financially by the Australian Biological Resources Study. Thanks are due to Dr L. Warner for assistance in collecting wallabies, to Dr D.M. Spratt for comments on a draft of the manuscript and two anonymous referees for suggested improvements to the submitted manuscript.

\section{REFERENCES}

Baverstock P.R., Adams M. \& Beveridge I. Biochemical differentiation in bile duct cestodes and their marsupial hosts. Molecular Biology and Evolution, 1985, 2, 321-337.

BEVERIDge I. A taxonomic revision of the Anoplocephalidae (Cestoda: Cyclophyllidea) of Australian marsupials. Australian Journal of Zoology, Supplementary Series, 1976, 44, 1-110.

Beveridge I. Progamotaenia ruficola sp. n. (Cestoda: Anoplocephalidae) from the red kangaroo, Macropus rufus (Marsupialia). Journal of Parasitology, 1978, 64, 273-276.

Beveridge I. Progamotaenia Nybelin (Cestoda: Anoplocephalidae): new species, redescriptions and new host records. Transactions of the Royal Society of South Australia, 1980, 104, 67-79.

Beveridge I. Three new species of Progamotaenia (Cestoda: Anoplocephalidae) from Australasian marsupials. Systematic Parasitology, 1985, 7, 91-102.

Beveridge I., Chilton N.B., Johnson P.M., Smales L.R., Speare R. \& SpratT D.M. Helminth communities of kangaroos and wallabies (Macropus spp. and Wallabia bicolor) from north and central Queensland. Australian Journal of ZOO$\log y, 1998,46,473-495$. 
Beveridge I., Spratt D.M., Close R.L, Barker S.C. \& Sharman G.B. Helminth parasites of rock-wallabies, Petrogale spp. (Marsupialia), from Queensland. Australian Wildlife Research, 1989, 16, 273-287.

BEveridge I. \& Thompson R.C.A. The anoplocephalid cestode parasites of the spectacled hare-wallaby, Lagorchestes conspicillatus Gould, 1842 (Marsupialia: Macropodidae). Journal of Helminthology, 1979, 53, 153-160.

Pritchard M.H \& Kruse G.O.W. The Collection and Preservation of Animal Parasites. University of Nebraska Press, Lincoln, 1982, $141 \mathrm{pp}$.

Spratt D.M., Beveridge I. \& Walter E.L. A catalogue of Australasian monotremes and marsupials and their recorded helminth parasites. Records of the South Australian Museum, Monograph Series, 1991, 1, 1-105.

Turni C. \& Smales L.R. Progamotaenia abietiformis sp. nov. (Cestoda: Anoplocephalidae) from Onychogalea fraenata (Marsupialia: Macropodidae) from central Queensland. Transactions of the Royal Society of South Australia, 1999, 123, 143-147.

Reçu le 13 juin 2003

Accepté le 22 septembre 2003 